\title{
The Perception of Sex for Teenager and Application of Behavior: A Case Study at Department of Islamic Education of University of Muhammadiyah Sumatera Utara
}

\author{
Munawir Pasaribu \\ University of Muhammadiyah Sumatera Utara \\ munawirpasaribu@umsu.ac.id
}

\begin{abstract}
This research aims at knowing the perception of teenager sex that is studying at Departement of Islamic Religion in University Muhammadiyah of Sumatera Utara. In this research, the researcher wants to know students' knowledge about sex and theirbehavior in daily life. This research employsexplanatory research using the qualitative descriptive approach. This research was conducted atDepartment of Islamic Religion in University Muhammadiyah of Sumatera Utara Jl. KaptenMuktarBasri BA No. 3 Medan. The data were gathered from the interviews, observations and questionnaires. Those techniques were used to determine the level of students' understanding. Descriptive method was applied to analyze the data. The result of the study showed that students' level of understanding about sex is fairly good. Moreover, students' daily life did not show that they conducted misbehavior. It is also known that some of the students were dating, but their sexual behavior is classified into normal and reasonable.
\end{abstract}

Keyword: Sex, Teenagers, Behavior Introduction

\section{INTRODUCTION}

Nowadays, sex becomes the easiest merchandise to sell, in negative meaning. The word 'sex' is short; it consists only three letters. However, it seems taboo to be discussed. Yet it is a never-ending topic to talk and it arouses everyone's concern. [1].

Sex play an important role in our life. Newspapers, news media broadcasts expose the news on rape, free sex, prostitution and so on [2]. Almost every day newspapers and news media broadcast news about rape, free sex, prostitution and so forth related to the problem of sex itself [2]. This signifies that the role and sex activity is a very important issue, so an in-depth discussion should be carried out.

Teenagers, or young people in their baligh age, tend to be on the risk of sexual deviation problem. The lack of knowledge about sex awareness might be put them in having incorrect understanding of sexuality. When teenagers have wrong understanding, and have improper
Shari'a in their mind, it is possible that the destruction of morality happen to them [3].

Considering the phenomenon, which may lead to the practice of free intercourse, parents feel anxious. In addition, the level of anxiety has reached the high level that need special treatment from various parties. Religion leaders, education activists, and several government agencies are expected to handle this serious problem. Attention should be emphasized because the fast-growing media and facilities support the free intercourse activity. Everybody, poor and rich people can access the information. In this case, government policies do not seem provide a system that fight the degrading media. The seizure of dominance in the direction of negative freedom is possible if not immediately anticipated with intelligence [4].

This phenomenon is growing not only in Indonesia but also in the developing world. In Malaysia, based on an article written by Johari Talib et al, they said that teenagers in Malaysia get involved in sexual activity, which cause pre-marital pregnancy. This leads to the desire to have a partner at a young age, the spread of sexually transmitted diseases, a lot of illegitimate children, abortion, and the worst, her mother kills her unwanted child. Data of Malaysian Ministry of Health mentioned that there were $54 \%$ of respondents aged 17-24 stated that they had more than two sexual partners[5].

In the United States for example, the implementation of sexual activity increases so rapidly among adolescents, especially for women. One out of the teen US female teenagers experience an unwanted pregnancy each year, and over 400,000 give birth without legal marriage. In addition, one in four female teenagers have sexually transmitted diseases. This disease may be caused by sexual activity in the adolescent, which is associated with poorer emotional health; some say because of low selfesteem. Sexually active high school girls are almost five times more likely to be the victim of the sexual problem rather than women who are not sexually active[6].

A study conducted in India, particularly in Ambala area, has tried to assess knowledge, attitudes, and practices regarding reproductive health and sexual issues. Moreover, the study aims at assessing the perceptions of reproductive and sexual health among adolescents and to identify the need to inculcate adolescent sex education in 
intermediate schools (13- 19 years) from the urban and rural areas of Ambala Haryana district. In terms of the need for sex education among adolescents, the result shows that the majority of adolescents $(93.5 \%)$ prefer sex education. However, boys $(97.1 \%)$ were more likely to prefer sex education than women $(89.7 \%)$ [7].

The role of sex education also greatly affects teenagers in Italy. A study conducted by Nicoletta Landion anthropologists who get engaged in sex education concluded that adolescent knowledge about healthy sex certainly helps the country in shaping the good behavior of the teenagers.

The research mentions that anthropologist sare offered as a middle ground to promote healthy sex education. Sex education involves a wide range of stakeholders such as policymakers, health professionals, teachers, families, and youth. They each perform different socio-political visions of sex, sexuality, health, and adolescence. Sex education becomes the norm in society or it is used to empower adolescent access to information about normal sexual health. Anthropologists can highlight the complexity and important aspects of adolescent sexual promotion and, at the same time, advocate openly and suggest ways to implement sexuality education. In this frame, engagement, either as a theoretical approach or practical, can be a tool for incorporating anthropological education. In turn, the education can be publicly known as a knowledge which can provide information on healthy sex.[8] .

Students' attractiveness towards sexual activity is influenced by their own knowledge. However, it does not mean that they have a correct information about sexuality. This perhaps-wrong-understanding may lead to the high rate of promiscuity, and the teenagers do not aware of the risk they get in the future. In contrary, if the teenagers have proper knowledge about sexuality, they will understand the risk and they can avoid the wrongdoing related to promiscuity.

Candra Rukmana Dalimun the and Kristina Nadeak conducted a research on the Level of Knowledge of Free Sex with HIV / AIDS Risk at SMA Harapan-1 High School Students. The study found that students' knowledge of good sex has a good impact on the implementation of their good activities as well. Furthermore, the positive conduct result in the null risk of HIV/ [9].The data and facts showed that the participants of the research konw various perceptions of the view of sex, abuse of sexual activity and how to do healthy sex in everyday teenagers life.

The purpose of this study is to reveal how the actual perception of sex among teenagers and its implementation to the behavior of students at Islamic Education of Muhammadiyah University of North Sumatra. This study finds out how they behave in their daily life after they know and have a perception about sex.

\section{METHOD}

This research uses qualitative approach with explanatory research method. Explanatory research is mostly used in qualitative research. The goal is to reach beyond traditional descriptive design or a positive approach to give meaning and description. Explanatory research is applied to build a theory that explains and predicts natural and social events. The theory requires the development of a set of related laws that can be tested, for example statements that coordinate causal relationships among relevant variables. The ultimate goal of explanatory research is the control of natural and social events[10].

In terms of data collection, this research employs interviews, observations and questionnaires[11], [12]. Interviews refers to meeting with respondents and asking them related to the problems, which are presented in the form of daily activities and social activities in the community. The observation is conducted to see the activity of the respondents: activity in campus, activities in other environments such as boarding house and public places. The observations strengthen the result of the interviews. Questionnaires are given to determine the percentage of the activities. Moreover, questionnaires also support the result of interviews and observations.

Triangulation is used to validate the collected data. Researcher needs to ask more respondents about teenager sexuality and then match the answers to the interview. He then holds observations until he gets the valid result which provide maximum truth.

\section{RESULT}

The students' perception of sex for teenagers and its implementation of Islamic Religious Education of University of Muhammadiyah Sumatera Utara shows that sex they understand is not only related to genital or gender, but it also refers to an activity in everyday life. The data shows that out of thirty-two PAI students, $90.92 \%$ of them had received sex education in their daily life. There is only one person who had never received sex education. Next, the sex knowledge they received mostly come from the school teachers $(50.7 \%)$, from friends $(10.6 \%)$, from parents $(0.96 \%)$, from TV information $(0.96 \%)$, from internet browsing $(0.64 \%)$, and $(0.32 \%)$ from magazines. In terms of the acceptance of learning about the correct sex, the students get the information from teacher (70.04\%), and from parents $(2.88 \%)$. In this case, students have known the impact of the implementation of unhealthy sex.

In terms of virginity, the students agree that it is important to maintaining virginity. In addition, $80 \%$ of them said that they have been dating and $20 \%$ of them have never been dating. The respondents say that their dating activities are not categorized into free sex activity. 
Furthermore, $2.56 \%$ said that they had previously date more than three times, $1.28 \%$ had previously date twice, and $4.16 \%$ had previously date once.

The dating activity, according to the respondents, are kissing and holding hands. Those are the most 'serious' activities, which they felt fear and sinful when doing it in the first time. This is because they know the bad effects on unhealthy sex activities and can even destroy them. If it happens, they think that they will be useless in their society. Based on the interviews and observations, they know the consequences of their dating bad behavior. If they think they have gone too far, they decide not to continue their dating or break up with their boyfriend/ girlfriend. From the results of the study we can observe that the perception of sex for adolescents and its application in behavior of students in the Department of Islamic Religious Education of Muhammadiyah University of North Sumatra is still classified into fair and did not lead to misbehaved activities. Their initial knowledge gained form teachers and parents contribute to the understanding of sexuality.

\section{CONCLUSION}

Youth, as religious generation, who love their nation, must have a strong personality. They have to be wise enough and have a faith that prevent them from misbehavior. The perception of sex among teenagers and their application to the behavior of the students at the Faculty of Islamic Affairs of Muhammadiyah University of North Sumatra is still in fair extent and their understanding of sex is very good. Also, they do not get involved in worrying behavior.

\section{REFERENCES}

[1] H. Hathout, Panduan Seks Islam. Jakarta: Pustaka Zahra, 2004.

[2] J. L. C. Abineno, Seksualitas dan Pendidikan Seksual, 6th ed. Jakarta: Gunung Mulia, 2002.
[3] Y. Madani, Pendidikan Seks Untuk Anak Dalam Islam. Jakarta: Pustaka Zahra, 1995.

[4] A. Yus, Model Pendidikan Anak Usia DIni. Jakarta: Kencana, 2011.

[5] J. Talib, M. Mamat, M. Ibrahim, and Z. Mohamad, "Analysis on Sex Education in chools Across Malaysia," Procedia - Soc. Behav. Sci., vol. 59, no. 2005, pp. 340-348, 2012.

[6] T. Lickona, "Educating for Character in the Sexual Domain," Peabody J. Educ., vol. 88, no. 2, pp. 198-211, 2013.

[7] R. Kumar, A. Goyal, P. Singh, A. Bhardwaj, A. Mittal, and S. S. Yadav, "Knowledge attitude and perception of sex education among school going adolescents in Ambala district, Haryana, India: A cross-sectional study," J. Clin. Diagnostic Res., 2017.

[8] N. Landi, " Pleasure Is Not in the Science Programme!' When Anthropology Engages with Sex Education for Teenagers," Anthropol. Matters J., vol. 17, no. 1, pp. 120, 2017.

[9] C. R. Dalimunthe and K. Nadeak, "Tingkat Pengetahuan Pelajar SMA Harapan-1 Medan Tentang Seks Bebas Dengan Risiko HIV / AIDS," E-Journal FK USU, vol. 1, no. 1, pp. $1-4,2013$.

[10] D. E. MCNabb, Research Methods in Public Administrasion and Nonprofit Managemen Quantitative and Qualitative Approaches, 2nd ed. New York: Library Materials, 2008.

[11] L. J. Moleong, Metodologi Penelitian Kualitatif, Revisi. Bandung: PT Remaja Rosdakarya, 2005.

[12] J. Creswel, A Concise Introduction to Mixed Methods Research. London: Sage Publications, 2014. 